\title{
Stock Market Integration in South Asia
}

\author{
Damber Singh Kharka ${ }^{1}$, Prof. M.S.Turan ${ }^{2}$, Prof. K.P.Kaushik ${ }^{3}$ \\ ${ }^{1}$ Director, Druk Holding \& Investment, Thimphu: Bhutan, PhD student Haryana School of Business. \\ ${ }^{2}$ Former Dean \& Chairman, Haryana School of Business, GJUST, Hisar, Haryana. \\ ${ }^{3}$ Professor of Finance, NIFM, Faridabad, Haryana ,India
}

\section{ABSTRACT}

While the topic of stock market integration has been one of the highly researched area in the literature but focus had mostly been on the stock markets of developed economies. Few have focused on analyzing market integration in South Asian region and no inclusion of Bhutanese stock has been found in the literature in any of the earlier studies. The objective of this paper is to analyze market integration between Bhutanese, Indian and other indices in the region. We also analyzed whether other indices in the region are co-integrated with Indian stock market, as Indian market is more proficient in the region and can be believed to have influences on others. We analyzed all indices in the region on one to one basis (using pairwise co-integration test). We used weekly data from January 2006 to December 2011 period from the stock exchanges of (Bhutan, India, Nepal, Bangladesh, and Pakistan). Applying, Dickey-Fuller method, we tested unit root for each stock indices and used Johansen co-integration approach pairwise to test the long-term relationship between stock indices and multivariate approach to test market integration as a whole. We found that all indices are stationary at $\mathrm{I}(1)$ and confirmed no long-term relationship between Bhutanese stock with Indian and other regional stock markets.In fact we find no market integration either on one to one basis or for the south Asian market as a whole. Information on market integration should help market players in managing their investments in capital markets in a sustainable manner.
Keywords Stock market, integration, Bhutan, South Asia.

\section{INTRODUCTION}

Financial market integration in general implies that if there is absence of barriers for information flow then risk-adjusted returns on assets of the similar tenor in each market segment should be similar. If financial markets are integrated, we will find longterm relationship between market instruments; very popularly used instrument in analyzing market integration is stock indices.

In an effort to maximize benefits and minimize risk, the investors in the capital market do follow investment portfolio diversification. Portfolio diversification models (Markowitz, 1952; Sharpe, 1964, Lintner, 1965) have shown that if the comovement of stock markets is similar across stock markets then the gain from the portfolio diversification is not achievable. Co-movement of stock market returns can be analyzed through study of relationship or cointegration. Co-integration theory is unarguably is most popular approach that has created interest among researchers in analyzing long-term relationship between stock markets.Engle and Granger (1987), Johansen (1988), Johansen and Juselius (1990) are some of the eye openers in the literature in areas of stock market cointegration analysis. Masih and Masih (1996), Kasa (1992), Chowdhury(1994) and others have applied co-integration approach in assessing long-term relationships and levels of financial market integration 
between Asian and global markets and within Asian markets.

While the topic of stock market integration has been one of the highly researched area in the literature but focus had mostly been on the stock markets of developed economies. Few have focused on analyzing market integration in South Asian region. Among those who investigated co-movements of stock markets in South Asia in the recent times are: Gunasinghe (2005), Lamba (2005), Mohsim and Qayyum (2005), Hassan, Saleem and Abdullah (2008), Raj and Dhal (2008), Subhani, Hasan, Mehar and Osman (2011), Sharma and Bodla (2011), Saha and Bhunia (2012) Khan and Huq (2012) and others. In any of the past studies Bhutanese stock was never included probably due to unavailability of stock index data or because the Bhutanese market is too insignificant in the region due to its smallness in size and lack of frequency in trading.

\section{OBJECTIVES SIGNIFICANCE}

AND

The objective of this paper is to investigate long-term relationship between Bhutanese and Indian stock markets and extend the investigation between Bhutanese and other markets in the region. We also look at the pairwise co-integration for all indices (one to one basis) and investigate market integration in South Asia as a whole with multivariate model. This is the first study that looks into the Bhutanese stock market vis-a-vis other markets in the region.

Mukherjee (2004) states, "stock market integration or interdependence means that the investors can buy and sell shares in those markets without restriction and that identical securities can be issued and traded at the same price across the markets after foreign exchange adjustment". It is in this context, understanding trend of various stock markets is essential for investors and academia. If markets are integrated, any uncertainty in one market can spread to another market. Therefore, to be knowledgeable about the relationship between stock markets is essential for the policy makers and macroeconomic regulators also. Since this is the first study of this kind that includes Bhutanese stock market, it provides more inclusive information than the earlier studies.

\section{LITERATURE REVIEW}

We find several studies in the finance literature that concentrated their research on stock market integration. When we looked at South Asian markets, we find very limited studies. Some of the studies that have focused on South Asian markets that are relevant for our study given our research objectives and are presented here.

Sharma and Bodla (2010) studied India, Pakistan and Sri Lanka covering daily data from $1^{\text {st }}$ January 2003 to 30th June 2010 as these three countries are the most dominant ones in terms of trade and polity in the region. They firstly confirmed that all the three stock market data are stationary through unit-root test and conducted Granger causality test for each pair. They found that the Indian stock market Granger cause Pakistani and Sri Lankan stock markets and noother indices is found to Granger cause any other indices. The study also conducted variance decomposition analysis and reported that the stock markets in South Asia (represented by three indices) are not much influenced by each other. They concluded that there exist opportunities for investors to diversify their investment among South Asian countries.

Gunasinghe (2005) covered stock market of three countries Sri Lanka, India and Pakistan for 1997 - 2002 period. He conducted correlation analysis and co-integration test for 1992 - 1997 (full sample and after splitting the data) to see if there was any difference in integration behavior after economic liberalization initiated in early 1990s by these countries. He found out that the correlations between Indian stock and Sri Lankan stock and the Indian stock and Pakistani stock have marginally improved for 
the full sample against the results of split sample (1992-1997). However, his multivariate co-integration test did not indicate long-term relationship or integration between the stock markets in the region.

Mohsin and Qayyum (2005) studied inward and outward capital mobility between five South Asian countries (Pakistan, India, Bangladesh, Sri Lanka and Nepal). He analyzed market integration from saving and investment prospective. His findings did not support the hypothesis that there exists a perfect mobility of capital across the five countries, which indicates lack of economic integration. However, he observed that the capital mobility has improved after economic liberalization at least in Bangladesh and Nepal. He concluded that in general the financial markets in South Asia is not perfectly integrated among each other and with the rest of the world.

Lamba (2005) conducted a study to investigate short-term and long-term relationship of south Asian stock markets (India, Pakistan and Sri Lanka) with developed markets (US, UK and Japan). He looked at the correlations among different markets and elaborated the analysis using multivariate co-integration approach covering July 1997 - December 2003 data. He reported that the South Asian markets are relatively isolated from the developed stock markets but they are becoming more integrated with each other within the region at a very slow pace.

Hasan, Salem and Abdullah (2008) have studied long term relationship between Karachi Stock exchange and equity markets of developed countries (US, UK, Germany, Canada, Italy and Australia) covering $2000-$ 2006 period. They used multivariate cointegration approach advocated by Johansen and Juselius (1990). They reported that Karachi stock exchange data was not integrated with other developed countries' except with France and Japan.

Raj and Dhal (2008) looked at the integration of Indian stock market with global and regional markets. They studied correlations for different time intervals and looked at cointegration with full and split samples for Indian Stock (Bombay stock Exchange), Hong Kong, Singapore, Japan, UK and USA for 1993 to 2008 period. Their findings suggest that Indian stock market is globally integrated in terms of stock prices measured in US dollars but not in local currency. It was also reported that the Indian stock market provides better returns than that of global and regional markets. Within the Asian region, Singapore and Hong Kong market are reported to have more influence on Indian market whereas Japanese market has a weak influence.

Subhani, Hassan, Mehar and Osman (2011) analyzed co-integration for Asian stock markets that includes stock indices from four countries (India, Pakistan, Bangladesh and Nepal). They tested for each indices the presence of unit root applying Dickey and Fuller model and reported that for both (with and without differencing (first lag) there was presence of data non-stationary. Since the data was non-stationary, Johansen cointegration has been applied to see if markets were integrated. They analyzed multivariate co-integration between Pakistani stock and the rest and they failed to accept the hypothesis of no co-integration in the equity market in South Asian region. However, when co-integration was analyzed on one to one basis between Pakistani stock and the rest, the finding suggested that Pakistani and Bangladeshi markets are co-integrated but with Indian and Nepalese markets there was no co-integration.

Saha and Bhunia (2012) studied relationship between Indian stock and leading South Asian markets between August 2002 and August 2011. They initially looked at the correlation matrix among the stock markets in the region and since Indian stock was observed having relationship with others, it was thought that Indian stock as a more proficient market in the region has some influence on the others. He also tested each variable for unit root and applied bivariate and multivariate co-integration (Johansen co- 
integration approach) and Granger causality test to see if South Asian stock market is integrated. He concluded that there is ample opportunity for the investors to broaden the horizon of their investment in the capital market in the region to take advantage of the poor integration.

Khan and Huq (2012) focused their studies on the risk and return behavior of different stock indices of Bangladesh. They used three stock indices of Bangladesh stock exchange covering (2002 - 2010) period to analyze risk-return pattern. They used daily, weekly and monthly data to analyze descriptive statistics and variances for each index and found inconsistency between risk and returns indicating that an investor can achieve better returns without any additional risk. This suggests that even in the same country, the different stock indices are not integrated or closely related.

\section{METHODOLOGY IN CO- INTEGRATION PROCESS}

If two stock markets are integrated, we find close relationship between their returns. However, relationships measured through ordinary regression forone random variable against another random variable, leads to spurious resultsmore often than not. The conventional significance tests will tend to indicate a relationship between the two variables even if it does not exist. This is one reason why it is important to test for random walks of variables especially while dealing with time series data as they seem to follow random walk. Detrending the variables before running regression doe not help since the detrended series will still be nonstationary. Therefore, in order to create a stationary data series, we need to firstdifference the series. Pindyck and Rubinfeld (1991) in their book titled "Econometric Models and Economic Forecasts", (third edition) provide a simple explanation of Dickey-Fuller unit root test procedure (1976 and 1979) and the same is reviewed and presented, which will be applied in analyzing the unit root for stock indices of south Asian market, the focus of our study.

Suppose we believe that a variable $\mathrm{y}_{\mathrm{t}}$, which has been growing over time, it can be described by the following equation

$\mathrm{y}_{\mathrm{t}}=\alpha+\beta \mathrm{t}+\rho \mathrm{y}_{\mathrm{t}-1}+\varepsilon \mathrm{t}$

One possibility is that $\mathrm{y}_{\mathrm{t}}$ has been growing because it has a positive trend $(\beta>0)$, but would be stationary after detrending (i.e, $\rho<$ 1). In this case, $y_{t}$ could be used in a regression, and all the results and tests as per ordinary least square method would apply. However, there is another possibility, that is, $y_{t}$ has been growing because it follows random walks with positive drift (i.e, $\alpha>0, \beta$ $=0$ and $\rho=1$ ). In such case, we should work with $\Delta \mathrm{y}_{\mathrm{t}}$. Detrending will not make the series stationary and inclusion of $y_{t}$ in a regression (even if detrended) could lead to spurious results.

We use the equation of the form:

$\mathrm{y}_{\mathrm{t}}=\alpha+\beta \mathrm{t}+\rho \mathrm{y}_{\mathrm{t}-1}+\lambda \Delta \mathrm{y}_{\mathrm{t}-1}+\varepsilon \mathrm{t}$

where $\Delta \mathrm{y}_{\mathrm{t}-1}=\mathrm{y}_{\mathrm{t}-1}-\Delta \mathrm{y}_{\mathrm{t}-2}$. Additional lags of $\Delta y_{t}$ can be used on the right hand side. Using ordinary least square, we run the unrestricted regression of the following form.

$\mathrm{y}_{\mathrm{t}}-\mathrm{y}_{\mathrm{t}-1}=\alpha+\beta \mathrm{t}+(\rho-1) \mathrm{y}_{\mathrm{t}-1}+\lambda \Delta \mathrm{y}_{\mathrm{t}-1}$

and then the restricted regression of the form

$\mathrm{y}_{\mathrm{t}}-\mathrm{y}_{\mathrm{t}-1}=\alpha+\lambda \Delta \mathrm{y}_{\mathrm{t}-1}$

With the parameter estimates from unrestricted and restricted regression we calculate the standard $\mathrm{F}$ ratio and compare with the critical value of $F$ statistics to test whether $(\beta=0, \rho=1)$ holds at different significant levels (usually at $1 \%$ and $5 \%$ ). We reject the null hypothesis of a unit root if calculated value of F-statistic is greater than the critical values of $\mathrm{F}$ given for different significant levels. Alternatively, coefficients produced by the Dickey-Fuller test can be judged against t-stats and p-values analyze the presence of unit roots.

After we determine that stock indices for different markets (x, y, z..) that follow random walks where $\Delta \mathrm{x}_{\mathrm{t}}, \Delta \mathrm{y}_{\mathrm{t}}$ and $\Delta \mathrm{z}_{\mathrm{t}}$ are stationary, it will be easy to test if $\mathrm{x}_{\mathrm{t}}$ and $\mathrm{y}_{\mathrm{t}}$ are co-integrated or similarly if $x_{t}$ and $z_{t}$ or any other pairs are co-integrated. 
Upon confirming that individual data series are stationary we can test market cointegration using the following regression equation.

$\mathrm{y}_{\mathrm{t}}=\beta_{0}+\beta_{1} \mathrm{x}_{\mathrm{t}}+\varepsilon_{\mathrm{t}}$

From the results obtained in equation (5),we test whether $\varepsilon_{\mathrm{t}}$ are stationary. If $\mathrm{y}_{\mathrm{t}}$ and $\mathrm{x}_{\mathrm{t}}$ are not co-integrated, any linear combination of two variables will be non-stationary and hence residual $\varepsilon_{\mathrm{t}}$ will be non-stationary or exists no co-integration. To see if $\varepsilon_{\mathrm{t}}$ is nonstationary, we can either perform DickeyFuller test on residuals or simply look at the Durbin-Watson statistics from the cointegration regression. However, most popularly used approach has been Johansen co-integration test.

Johansen testing approach (1988) as reflected in Tong (2001) is a vector from of the errorcorrection model of the following form.

$\Delta X t=\sum_{i=1}^{k-1} \Gamma i \Delta X t-1-\prod X t-k+\varepsilon t$ (6)

where $\Gamma i=-\mathrm{I}+\Pi+1+\ldots \ldots+\prod i,(\mathrm{i}=1$, $\ldots ., \mathrm{k}-1)$ and $\Pi=\mathrm{I}-\Pi 1-\cdots . \Pi \mathrm{k}$.

$X_{t}$ is an $n X 1$ vector of $I(1)$ variables and is an $n X n$ matrix that has rank $r<n$ if $X_{t}$ are co-integrated. To determine $r$, Johansen uses two statistics. One is the maximal eigenvalue statistic (the Lambda-Max test), which tests the null hypothesis of rank equal $r-1$ against the alternative of rank equal to $r$. The other test is the Trace statistic, which tests the null hypothesis of rank of $r$ against the alternative of full rank. Johansen (1988) and Johansen and Juselius (1990) may provide details on Johansen approach.This study follows
Johansen approach in conducting cointegration test.

In investigation our research objectives weekly data has been pooled for January 2006 to December 2011 period from the stock exchanges of (Bhutan, India, Nepal, Bangladesh, and Pakistan). Applying, Dickey-Fuller method, we tested unit root for each stock indices and used Johansen cointegration approach pairwise to test the long-term relationship between stock indices.

\section{RESULTS \& DISCUSSION}

This section presents the results and discussion thereof. To start with the results on unit root test following Dickey and Fuller is presented followed by the results on cointegration test.

\subsection{Results for Unit Root}

In table 1, we have presented the results for unit root using Augmented Dickey and Fuller (ADF) test equation firstly with same order with just the intercept and with intercept and trend for all the stock indices. When analysis is conducted for same order without trend we find presence of unit root for all stock indices or we could not reject that here is no random walk. When the model is repeated for same order with intercept and trend, except for Bhutanese stock that has (T-stat of -3.466446 and $\mathrm{P}$-value of 0.0006 confirming significant at $5 \%$ ) rest of the indices still show that the series are non-stationary or could not reject the hypothesis that there exist no random walk.

Table 1. Augmented Dickey-Fuller (ADF) Unit Root Test at same Order

\begin{tabular}{|c|c|c|c|c|c|c|}
\hline \multirow{2}{*}{$\begin{array}{c}\text { Variables - } \\
\text { stock indices }\end{array}$} & \multicolumn{3}{|c|}{$\begin{array}{c}\text { ADF with intercept and no trend at same } \\
\text { level }\end{array}$} & \multicolumn{2}{c|}{ ADF with intercept and trend at same } \\
& Order \\
\cline { 2 - 7 } & Coeff & T-stat & P-value & Coeff & T-sata & P-value \\
\hline Bhutan & $-0.022452(2)$ & -0.924696 & 0.3559 & $-0.115627(2)$ & -3.46446 & 0.0006 \\
\hline India & $-0.019126(0)$ & -1.99646 & 0.0468 & $-0.021452(0)$ & -1.78446 & 0.0753 \\
\hline Nepal & $-0.01013(0)$ & -1.266638 & 0.2062 & $-0.013238(0)$ & -1.63086 & 0.1039 \\
\hline Bangladesh & $-0.003913(1)$ & -0.927007 & 0.3546 & $-0.012694(1)$ & -1.40572 & 0.1608 \\
\hline Sri Lanka & $-0.000706(0)$ & -0.202902 & 0.8393 & $-0.006012(0)$ & -1.0521 & 0.2936 \\
\hline
\end{tabular}




\begin{tabular}{|c|c|c|c|c|c|c|}
\hline Pakistan & -0.014117 & -1.496677 & 0.1355 & $-0.014544(0)$ & -1.52543 & 0.1282 \\
\hline \multicolumn{6}{c|}{ Mackinnon Critical values } \\
$1 \%$ & -16.2187 \\
$5 \%$ & -3.4512 & \\
& $10 \%$ & -2.5717
\end{tabular}

Figures in parenthesis are the lag order in ADF equation that was selected based on the Schwartz criterion.

In table 2 presents the results for unit root using ADF with first order differencing. We found that both with intercept and intercept with trend the calculated T-stats are much higher than the critical values even at $1 \%$ significance level. As indicated by the pvales of (0.0000) in all cases, we reject the hypothesis that there is presence of unit root at first order differencing. Hence we can say that the series are stationary at first order differencing. We conclude that all the stock indices that are considered in our study (six stock exchanges in South Asian region) are integrated of order one that is, they are I(1). As reported by Subhani, Hasan, Mehar and Osman (2011), we also found that all the South Asian stock markets have series nonstationary at the same order but stationary at first order difference. The only difference between them and our work is that we included six countries whereas they had only four.

Table 2. Augmented Dickey-Fuller (ADF) Unit Root Test at 1st Difference

\begin{tabular}{|c|c|c|c|c|c|c|}
\hline \multirow{2}{*}{$\begin{array}{c}\text { Variables - } \\
\text { stock indices }\end{array}$} & \multicolumn{3}{|c|}{$\begin{array}{c}\text { ADF with intercept and no trend with 1 } \\
\text { difference }\end{array}$} & \multicolumn{2}{c|}{ ADF with intercept and Trend with ${ }^{\text {st }}$} \\
& difference \\
\cline { 2 - 7 } & Coeff & T-stat & P-value & Coeff & T-sata & P-value \\
\hline Bhutan & $-1.422101(1)$ & -18.6353 & 0.0000 & $-1.42245(1)$ & -18.61050 & 0.0000 \\
\hline India & $-0.859533(1)$ & -10.68172 & 0.0000 & $-0.86481(1)$ & -10.71123 & 0.0000 \\
\hline Nepal & $-0.962632(0)$ & -16.93334 & 0.0000 & $-0.97142(0)$ & -17.05497 & 0.0000 \\
\hline Bangladesh & $-0.852586(0)$ & -15.14315 & 0.0000 & $-0.85299(0)$ & -15.12393 & 0.0000 \\
\hline Sri Lanka & $-0.937423(0)$ & -16.52035 & 0.0000 & $-0.93826(0)$ & -16.50539 & 0.0000 \\
\hline Pakistan & $-0.918256(0)$ & -16.21872 & 0.0000 & $-0.91826(0)$ & -16.19214 & 0.0000 \\
\hline \multicolumn{7}{|c|}{$\begin{array}{c}\text { Mackinnon Critical values } \\
1 \%\end{array}-3.9878$} \\
$5 \%$ & -3.4234 \\
$10 \%$ & -3.1352 \\
Figures in parenthesis are the lag order in ADF equation that was selected based on the Schwartz \\
criterion
\end{tabular}

\subsection{Results for Co-integration Analysis}

As we found no evidence of unit root in each stock market at the first differencing, we proceeded with the test of co-integration using Johansen approach. Firstly, we applied bivariatepairwise co-integration to see whether Bhutanese stock is integrated with Indian stock and also with others in the region. We also analyzed co-integration between each pairs; there are 15 pairs as we have six indices for which any two are taken at a time.Data for each series is converted into $\log$ form for this purpose.

Johansen co-integration test for pairwise stock indices has been conducted using two models (with deterministic trend and with linear deterministic trend) at first differences. Table 3 presents the finding from the first 
model. As we compare Trace statistics and Lambda-Max statistics against respective critical values at $5 \%$, we do not reject the null hypothesis of "no co-integration" between Bhutan and India and Bhutan and any other market in the region. In fact, we find no cointegration between any pair in the region. This shows that none of the stock indices in South Asian markets is co-integrated with any other stock indices in the region. To further confirm this, we have also conducted a pairwise co-integration using second model (with linear trend at first difference). Results are presented in table 4 . We observe that the second model also provides similar results for all the pairs except that between (Bhutanese and Indian stock), (Bhutanese and Pakistani stock) and (Indian and Pakistani stock) some co-integration either at
$5 \%$ or $10 \%$ with Trace statistics or LambdaMaxare observed. However, in all these three pairs results are confusing since two tests (Trace and Lambda-Max) provide different conclusions. What may be derived in general from table 3 and 4 is thatthe Bhutanese stock market is not co-integrated with Indian stock market nor it is co-integrated with anyother market in the region. Similarly, no stock market in the region is co-integrated with any other market in the region. Our finding confirms the findings of Saha and Bhunia (2012) that reported, none of the South Asian markets has any control over each other. Further they stated that none of the South Asian market leads the Indian stock market nor they are being influenced by Indian stock market.

Table 3. Johansen Co-integration (no deterministic trend)

\begin{tabular}{|c|c|c|c|c|c|c|c|c|}
\hline \multicolumn{9}{|c|}{ No Deterministic Trend (first order differences) } \\
\hline $\begin{array}{l}\text { Variable } \\
\text { Pairs } \\
\end{array}$ & & \multicolumn{3}{|c|}{ Trace - Rank Test } & \multicolumn{3}{|c|}{$\begin{array}{c}\text { Maximum Eigenvalue- } \\
\text { Rank Test }\end{array}$} & \multirow[b]{2}{*}{$\begin{array}{l}\text { Hypothe } \\
\text { sis of } \\
\text { "No Co- } \\
\text { integrati } \\
\text { on }\end{array}$} \\
\hline & $\begin{array}{c}\text { Hypothesi } \\
\text { zed No. of } \\
\text { CE(s) }\end{array}$ & $\begin{array}{l}\text { Trace } \\
\text { Stat }\end{array}$ & $\begin{array}{c}\text { Critical } \\
\text { value at } \\
5 \%\end{array}$ & Prob. & $\begin{array}{c}\text { Max- } \\
\text { Eigen } \\
\text { Stat }\end{array}$ & $\begin{array}{c}\text { Critical } \\
\text { value at } \\
5 \%\end{array}$ & Prob & \\
\hline \multirow{2}{*}{$\begin{array}{l}\text { LBHU \& } \\
\text { LBSE }\end{array}$} & & 10.2459 & 12.3209 & 0.1087 & 8.0791 & 11.2248 & & \multirow{2}{*}{$\begin{array}{l}\text { Not } \\
\text { rejected }\end{array}$} \\
\hline & At most 1 & 2.1668 & 4.1299 & 0.1663 & 2.1668 & 4.1299 & 0.1663 & \\
\hline \multirow{2}{*}{$\begin{array}{l}\text { LBHU \& } \\
\text { LNPL }\end{array}$} & None & 4.1113 & 12.3209 & 0.6948 & 3.4190 & 11.2248 & 0.7216 & \multirow{2}{*}{$\begin{array}{l}\text { Not } \\
\text { rejected }\end{array}$} \\
\hline & At most 1 & 0.6923 & 4.1299 & 0.4647 & 0.6923 & 4.1299 & 0.4647 & \\
\hline \multirow{2}{*}{$\begin{array}{l}\text { LBHU \& } \\
\text { LBGD }\end{array}$} & None & 6.9725 & 12.3209 & 0.3278 & 5.8507 & 11.2248 & 0.3670 & \multirow{2}{*}{$\begin{array}{l}\text { Not } \\
\text { rejected }\end{array}$} \\
\hline & At most 1 & 1.1218 & 4.1299 & 0.3371 & 1.1218 & 4.1299 & 0.3371 & \\
\hline \multirow{2}{*}{$\begin{array}{l}\text { LBHU \& } \\
\text { LSLK }\end{array}$} & None & 5.4832 & 12.3209 & 0.5017 & 4.3524 & 11.2248 & 0.5731 & \multirow{2}{*}{$\begin{array}{l}\text { Not } \\
\text { rejected }\end{array}$} \\
\hline & At most 1 & 1.1308 & 4.1299 & 0.3349 & 1.1308 & 4.1299 & 0.3349 & \\
\hline \multirow{2}{*}{$\begin{array}{l}\text { LBHU \& } \\
\text { LPAK }\end{array}$} & None & 7.6378 & 12.3209 & 0.2661 & 6.4023 & 11.2248 & 0.3062 & \multirow{2}{*}{$\begin{array}{l}\text { Not } \\
\text { rejected }\end{array}$} \\
\hline & At most 1 & 1.2355 & 4.1230 & 0.3108 & 1.2355 & 4.1299 & 0.3108 & \\
\hline \multirow{2}{*}{$\begin{array}{l}\text { LNPL \& } \\
\text { LBSE }\end{array}$} & None & 1.2755 & 12.3209 & 0.9892 & 1.0365 & 11.2248 & 0.9912 & \multirow{2}{*}{$\begin{array}{l}\text { Not } \\
\text { rejected }\end{array}$} \\
\hline & At most 1 & 0.2390 & 4.1299 & 0.6835 & 0.2390 & 4.1299 & 0.6835 & \\
\hline LNPL \& & None & 3.8546 & 12.3209 & 0.7318 & 3.6394 & 11.2248 & 0.6862 & Not \\
\hline
\end{tabular}




\begin{tabular}{|c|c|c|c|c|c|c|c|c|}
\hline LBGD & At most 1 & 0.2152 & 4.1299 & 0.6996 & 0.2152 & 4.1299 & 0.6996 & rejected \\
\hline \multirow{2}{*}{$\begin{array}{l}\text { LNPL \& } \\
\text { LSLK }\end{array}$} & None & 1.5216 & 12.3209 & 0.9797 & 1.4310 & 11.2248 & 0.9724 & \multirow{2}{*}{$\begin{array}{l}\text { Not } \\
\text { rejected }\end{array}$} \\
\hline & At most 1 & 0.0906 & 4.1299 & 0.8047 & 0.0906 & 4.1299 & 0.8047 & \\
\hline \multirow{2}{*}{$\begin{array}{c}\text { LNPL \& } \\
\text { LPAK }\end{array}$} & None & 2.9966 & 12.3209 & 0.8481 & 2.9966 & 11.2248 & 0.7883 & \multirow{2}{*}{$\begin{array}{l}\text { Not } \\
\text { rejected }\end{array}$} \\
\hline & At most 1 & 0.0042 & 4.1299 & 0.9984 & 0.0042 & 4.1299 & 0.9984 & \\
\hline \multirow{2}{*}{$\begin{array}{l}\text { LBGD \& } \\
\text { LBSE }\end{array}$} & None & 4.1115 & 12.3209 & 0.6947 & 4.0997 & 11.2248 & 0.6126 & \multirow{2}{*}{$\begin{array}{l}\text { Not } \\
\text { rejected }\end{array}$} \\
\hline & At most 1 & 0.0118 & 4.1299 & 0.9293 & 0.0118 & 4.1299 & 0.9293 & \\
\hline \multirow{2}{*}{$\begin{array}{l}\text { LBGD \& } \\
\text { LPAK }\end{array}$} & None & 3.5957 & 12.3209 & 0.7683 & 3.0858 & 11.2248 & 0.7744 & \multirow{2}{*}{$\begin{array}{l}\text { Not } \\
\text { rejected }\end{array}$} \\
\hline & At most 1 & 0.5099 & 4.1299 & 0.5381 & 0.5099 & 4.1299 & 0.5381 & \\
\hline \multirow{2}{*}{$\begin{array}{l}\text { LBGD \& } \\
\text { LSLK }\end{array}$} & None & 5.8159 & 12.3209 & 0.4588 & 3.2428 & 11.2248 & 0.7498 & \multirow{2}{*}{$\begin{array}{l}\text { Not } \\
\text { rejected }\end{array}$} \\
\hline & At most 1 & 2.5731 & 4.1299 & 0.1284 & 2.5731 & 4.1299 & 0.1284 & \\
\hline \multirow{2}{*}{$\begin{array}{c}\text { LSLK \& } \\
\text { LBSE }\end{array}$} & None & 1.8137 & 12.3209 & 0.9636 & 1.7592 & 11.2248 & 0.9470 & \multirow{2}{*}{$\begin{array}{l}\text { Not } \\
\text { rejected }\end{array}$} \\
\hline & At most 1 & 0.0545 & 4.1299 & 0.8482 & 0.0545 & 4.1299 & 0.8482 & \\
\hline \multirow{2}{*}{$\begin{array}{c}\text { LSLK \& } \\
\text { LPAK }\end{array}$} & None & 3.4823 & 12.3209 & 0.7840 & 2.0505 & 11.2248 & 0.9173 & \multirow{2}{*}{$\begin{array}{l}\text { Not } \\
\text { rejected }\end{array}$} \\
\hline & At most 1 & 1.4318 & 4.1299 & 0.2711 & 1.4318 & 4.1299 & 0.2711 & \\
\hline \multirow{2}{*}{$\begin{array}{l}\text { LPAK \& } \\
\text { LBSE }\end{array}$} & None & 9.5918 & 12.3209 & 0.1374 & 9.3633 & 11.2248 & 0.1044 & \multirow{2}{*}{$\begin{array}{l}\text { Not } \\
\text { rejected }\end{array}$} \\
\hline & At most 1 & 0.2286 & 4.1299 & 0.6904 & 0.2286 & 4.1299 & 0.6904 & \\
\hline
\end{tabular}

Table 4. Johansen Co-integration (Linear deterministic trend)

\begin{tabular}{|c|c|c|c|c|c|c|c|c|}
\hline \multicolumn{9}{|c|}{ Linear deterministic Trend (first order differences) } \\
\hline \multirow[t]{2}{*}{$\begin{array}{l}\text { Variable } \\
\text { Pairs } \\
\end{array}$} & & \multicolumn{3}{|c|}{ Trace - Rank Test } & \multicolumn{3}{|c|}{$\begin{array}{c}\text { Maximum Eigenvalue- Rank } \\
\text { Test }\end{array}$} & \multirow[b]{2}{*}{$\begin{array}{l}\text { Hypothe } \\
\text { sis of } \\
\text { "No Co- } \\
\text { integrati } \\
\text { on }\end{array}$} \\
\hline & $\begin{array}{c}\text { Hypothesi } \\
\text { zed No. of } \\
\text { CE(s) }\end{array}$ & $\begin{array}{l}\text { Trace } \\
\text { Stat }\end{array}$ & $\begin{array}{c}\text { Critica } \\
1 \text { value } \\
\text { at } 5 \%\end{array}$ & Prob. & $\begin{array}{l}\text { Max- } \\
\text { Eigen } \\
\text { Stat }\end{array}$ & $\begin{array}{c}\text { Critical } \\
\text { value at } \\
5 \%\end{array}$ & Prob. & \\
\hline \multirow{2}{*}{$\begin{array}{l}\text { LBHU \& } \\
\text { LBSE }\end{array}$} & None & 10.2860 & 15.4947 & 0.2594 & 7.1286 & 14.2646 & 0.4741 & \multirow{2}{*}{$\begin{array}{c}\text { not } \\
\text { rejected } \\
* * \\
\end{array}$} \\
\hline & At most 1 & 3.1574 & 3.8415 & 0.0756 & 3.1574 & 3.8415 & 0.0756 & \\
\hline \multirow{2}{*}{$\begin{array}{l}\text { LBHU \& } \\
\text { LNPL }\end{array}$} & None & 22.5612 & 25.8721 & 0.1223 & 16.1807 & 19.3870 & 0.1377 & \multirow{2}{*}{$\begin{array}{l}\text { not } \\
\text { rejected }\end{array}$} \\
\hline & At most 1 & 6.3805 & 12.5180 & 0.4136 & 6.3805 & 12.5180 & 0.4136 & \\
\hline \multirow{2}{*}{$\begin{array}{l}\text { LBHU \& } \\
\text { LBGD }\end{array}$} & None & 17.7093 & 25.8721 & 0.3638 & 15.0454 & 19.3870 & 0.1912 & \multirow{2}{*}{$\begin{array}{l}\text { not } \\
\text { rejected }\end{array}$} \\
\hline & At most 1 & 2.6639 & 12.5180 & 0.9139 & 2.6639 & 12.5180 & 0.9139 & \\
\hline \multirow{2}{*}{$\begin{array}{l}\text { LBHU \& } \\
\text { LSLK }\end{array}$} & None & 18.5980 & 25.8721 & 0.3051 & 15.7586 & 19.3870 & 0.1559 & \multirow{2}{*}{$\begin{array}{l}\text { not } \\
\text { rejected }\end{array}$} \\
\hline & At most 1 & 2.8394 & 12.5180 & 0.8950 & 2.8394 & 12.5180 & 0.8950 & \\
\hline LBHU \& & None & 28.6574 & 25.8721 & 0.0219 & 23.8896 & 19.3870 & 0.0105 & not \\
\hline
\end{tabular}




\begin{tabular}{|c|c|c|c|c|c|c|c|c|}
\hline LPAK & At most 1 & 4.7678 & 12.5180 & 0.6300 & 4.7678 & 12.5180 & 0.6300 & $\begin{array}{c}\text { conclusi } \\
\text { ve } *\end{array}$ \\
\hline \multirow{2}{*}{$\begin{array}{c}\text { LNPL \& } \\
\text { LBSE }\end{array}$} & None & 14.2627 & 25.8721 & 0.6359 & 8.1317 & 19.3870 & 0.8096 & \multirow{2}{*}{$\begin{array}{c}\text { not } \\
\text { rejected }\end{array}$} \\
\hline & At most 1 & 6.1310 & 12.5180 & 0.4438 & 6.1310 & 12.5180 & 0.4438 & \\
\hline \multirow{2}{*}{$\begin{array}{l}\text { LNPL \& } \\
\text { LBGD }\end{array}$} & None & 10.9527 & 25.8721 & 0.8779 & 7.7237 & 19.3870 & 0.8455 & \multirow{2}{*}{$\begin{array}{c}\text { not } \\
\text { rejected }\end{array}$} \\
\hline & At most 1 & 3.2291 & 12.5180 & 0.8482 & 3.2291 & 12.5180 & 0.8482 & \\
\hline \multirow{2}{*}{$\begin{array}{l}\text { LNPL \& } \\
\text { LSLK }\end{array}$} & None & 12.9371 & 25.8721 & 0.7431 & 7.3977 & 19.3870 & 0.8718 & \multirow{2}{*}{$\begin{array}{c}\text { not } \\
\text { rejected }\end{array}$} \\
\hline & At most 1 & 5.5395 & 12.5180 & 0.5209 & 5.5395 & 12.5180 & 0.5209 & \\
\hline \multirow{2}{*}{$\begin{array}{l}\text { LNPL \& } \\
\text { LPAK }\end{array}$} & None & 13.3231 & 25.8721 & 0.7127 & 8.4155 & 19.3870 & 0.7828 & \multirow{2}{*}{$\begin{array}{c}\text { not } \\
\text { rejected }\end{array}$} \\
\hline & At most 1 & 4.9076 & 12.5180 & 0.6097 & 4.9076 & 12.5180 & 0.6097 & \\
\hline \multirow{2}{*}{$\begin{array}{l}\text { LBGD \& } \\
\text { LBSE }\end{array}$} & None & 15.4185 & 25.8721 & 0.5399 & 12.6132 & 19.3870 & 0.3602 & \multirow[t]{2}{*}{$\begin{array}{c}\text { not } \\
\text { rejected }\end{array}$} \\
\hline & At most 1 & 2.8053 & 12.5180 & 0.8988 & 2.8053 & 12.5180 & 0.8988 & \\
\hline \multirow{2}{*}{$\begin{array}{l}\text { LBGD \& } \\
\text { LPAK }\end{array}$} & None & 9.2844 & 25.8721 & 0.9518 & 6.5345 & 19.3870 & 0.9296 & \multirow[t]{2}{*}{$\begin{array}{c}\text { not } \\
\text { rejected }\end{array}$} \\
\hline & At most 1 & 2.7500 & 12.5180 & 0.9048 & 2.7500 & 12.5180 & 0.9048 & \\
\hline \multirow{2}{*}{$\begin{array}{l}\text { LBGD \& } \\
\text { LSLK }\end{array}$} & None & 5.4040 & 25.8721 & 0.9994 & 3.1859 & 19.3870 & 0.9997 & \multirow[t]{2}{*}{$\begin{array}{c}\text { not } \\
\text { rejected }\end{array}$} \\
\hline & At most 1 & 2.2181 & 12.5180 & 0.9537 & 2.2181 & 12.5180 & 0.9537 & \\
\hline \multirow{2}{*}{$\begin{array}{l}\text { LSLK \& } \\
\text { LBSE }\end{array}$} & None & 11.8806 & 25.8721 & 0.8202 & 9.3636 & 19.3870 & 0.6866 & \multirow{2}{*}{$\begin{array}{c}\text { not } \\
\text { rejected }\end{array}$} \\
\hline & At most 1 & 2.5170 & 12.5180 & 0.9283 & 2.5170 & 12.5180 & 0.9283 & \\
\hline \multirow{2}{*}{$\begin{array}{l}\text { LSLK \& } \\
\text { LPAK }\end{array}$} & None & 14.7478 & 25.8721 & 0.5955 & 12.0729 & 19.3870 & 0.4084 & \multirow{2}{*}{$\begin{array}{c}\text { not } \\
\text { rejected }\end{array}$} \\
\hline & At most 1 & 2.6749 & 12.5180 & 0.9127 & 2.6749 & 12.5180 & 0.9127 & \\
\hline \multirow{2}{*}{$\begin{array}{l}\text { LPAK \& } \\
\text { LBSE }\end{array}$} & None & 23.2226 & 25.8721 & 0.1032 & 17.4792 & 19.3870 & 0.0926 & \multirow{2}{*}{$\begin{array}{l}\text { not } \\
\text { rejected } \\
* *\end{array}$} \\
\hline & At most 1 & 5.7434 & 12.5180 & 0.4935 & 5.7434 & 12.5180 & 0.4935 & \\
\hline
\end{tabular}

While we found out that none of the south Asian stock market is integrated with any other market in the region as seen through the bivariate (pairwise) co-integration results, it is important to conform through the multivariate co-integration model. Multivariate model is useful in testing whether there exists market integration as a whole in South Asian stock market. We ran all possible equations (no deterministic trend, no deterministic trend with restricted constant, linear deterministic trend, linear deterministic trend with restricted constant) for multivariate model. Lag structures are chosen according to Schwarz criterion and it has picked up first order differences for all the models. Results are presented in a sequential fashion for each model in tables 5 -8 below. The hypothesis of no cointegrating vectors at $\mathrm{r}<=0$ against the alternative of one or more co-integrating vectors is rejected. The hypothesis of "no cointegration" in the regional stock markets (as a whole) for $(r>0)$ is not rejected both by Johansen Trace and Lambda-Max tests in all the models (tables 5 - 8). Johansen (1988) attaches more importance to the first vector as he states that it corresponds to the highest eigen value among all ranks and it is the one that is believed to capture long-term relationship between variables. From the results obtained from the multivariate models we do not see even one stock market series 
co-integrated in the six-variable (six stock

indices)system

Table 5. Model with no deterministic trend

\begin{tabular}{|c|c|c|c|c|c|c|c|c|}
\hline \multicolumn{9}{|c|}{ No deterministic Trend (first order differences) } \\
\hline Variables & & \multicolumn{2}{|c|}{ Trace - Rank Test } & & \multicolumn{2}{|c|}{ Lambda-Max Test } & & \\
\hline \multirow{7}{*}{$\begin{array}{l}\text { LBHU, } \\
\text { LBSE, } \\
\text { LNPL, } \\
\text { LBGD, } \\
\text { LSLK, } \\
\text { LPAK }\end{array}$} & $\begin{array}{c}\text { Hypothesi } \\
\text { zed No. of } \\
\text { CE(s) }\end{array}$ & $\begin{array}{l}\text { Trace } \\
\text { Stat }\end{array}$ & $\begin{array}{c}\text { Critical } \\
\text { value at } \\
5 \%\end{array}$ & Prob. & $\begin{array}{c}\text { Lambda } \\
\text {-Max }\end{array}$ & $\begin{array}{c}\text { Critical } \\
\text { value at } \\
5 \%\end{array}$ & Prob. & $\begin{array}{l}\text { Hypothesis } \\
\text { of "No Co- } \\
\text { integration" }\end{array}$ \\
\hline & None & 87.1832 & 83.9371 & 0.0285 & 44.6964 & 36.6302 & 0.0046 & \multirow{6}{*}{$\begin{array}{c}\text { Reject at } \\
\mathrm{r}<=0 \text { and } \\
\text { not rejected } \\
\text { for all } \\
\text { ranks of } \\
\mathrm{r}>0\end{array}$} \\
\hline & At most 1 & 42.4867 & 60.0614 & 0.5920 & 19.6843 & 30.4396 & 0.5619 & \\
\hline & At most 2 & 22.8024 & 40.1749 & 0.7721 & 10.3248 & 24.1592 & 0.8983 & \\
\hline & At most 3 & 12.4776 & 24.2759 & 0.6658 & 7.1906 & 17.7973 & 0.7918 & \\
\hline & At most 4 & 5.2870 & 12.3209 & 0.5280 & 4.3876 & 11.2248 & 0.5676 & \\
\hline & At most 5 & 0.8997 & 4.1299 & 0.3967 & 0.8997 & 4.1299 & 0.3967 & \\
\hline
\end{tabular}

Table 6. Model with no deterministic trend with constant restriction

\begin{tabular}{|c|c|c|c|c|c|c|c|c|}
\hline \multicolumn{9}{|c|}{ No deterministic Trend (restricted constant - in first differences) } \\
\hline $\begin{array}{l}\text { Variable } \\
\text { Pairs }\end{array}$ & & \multicolumn{3}{|c|}{ Trace - Rank Test } & \multicolumn{3}{|c|}{ Lambda-Max Test } & \\
\hline \multirow{7}{*}{$\begin{array}{l}\text { LBHU, } \\
\text { LBSE, } \\
\text { LNPL, } \\
\text { LBGD, } \\
\text { LSLK, } \\
\text { LPAK }\end{array}$} & $\begin{array}{l}\text { Hypothesi } \\
\text { zed No. of } \\
\text { CE(s) }\end{array}$ & $\begin{array}{c}\text { Trace } \\
\text { Stat }\end{array}$ & $\begin{array}{c}\text { Critical } \\
\text { value at } \\
5 \%\end{array}$ & Prob. & $\begin{array}{l}\text { Lambda } \\
\text {-Max }\end{array}$ & $\begin{array}{c}\text { Critical } \\
\text { value at } \\
5 \%\end{array}$ & Prob. & $\begin{array}{l}\text { Hypothesis } \\
\text { of "No Co- } \\
\text { integration" }\end{array}$ \\
\hline & None & 106.7524 & 103.8473 & 0.0317 & 44.8444 & 40.9568 & 0.0174 & \multirow{6}{*}{$\begin{array}{c}\text { Rejected at } \\
\mathrm{r}<=0 \text { and } \\
\text { not rejected } \\
\text { for all } \\
\text { ranks of } \\
\mathrm{r}>0\end{array}$} \\
\hline & At most 1 & 61.9080 & 76.9728 & 0.3989 & 22.9190 & 34.8059 & 0.6044 & \\
\hline & At most 2 & 38.9891 & 54.0790 & 0.5217 & 18.9054 & 28.5881 & 0.4996 & \\
\hline & At most 3 & 20.0836 & 35.1928 & 0.7215 & 9.4226 & 22.2996 & 0.8772 & \\
\hline & At most 4 & 10.6610 & 20.2618 & 0.5750 & 6.3924 & 15.8921 & 0.7427 & \\
\hline & At most 5 & 4.2686 & 9.1645 & 0.3736 & 4.2686 & 9.1646 & 0.3736 & \\
\hline
\end{tabular}

Table 7. Model with Linear deterministic trend

\begin{tabular}{|c|c|c|c|c|c|c|c|c|}
\hline \multicolumn{9}{|c|}{ Linear deterministic Trend (in first differences) } \\
\hline Variables & & \multicolumn{3}{|c|}{ Trace - Rank Test } & \multicolumn{3}{|c|}{ Lambda-Max Test } & \multirow[b]{2}{*}{$\begin{array}{l}\text { Hypothesis } \\
\text { of "No Co- } \\
\text { integration" }\end{array}$} \\
\hline \multirow{4}{*}{$\begin{array}{l}\text { LBHU, } \\
\text { LBSE, } \\
\text { LNPL, } \\
\text { LBGD, } \\
\text { LSLK, } \\
\text { LPAK }\end{array}$} & $\begin{array}{c}\text { Hypothesi } \\
\text { zed No. of } \\
\text { CE(s) }\end{array}$ & $\begin{array}{c}\text { Trace } \\
\text { Stat }\end{array}$ & $\begin{array}{c}\text { Critical } \\
\text { value at } \\
5 \%\end{array}$ & Prob. & $\begin{array}{c}\text { Lambda } \\
\text {-Max }\end{array}$ & $\begin{array}{c}\text { Critical } \\
\text { value at } \\
5 \%\end{array}$ & Prob. & \\
\hline & None & 100.3510 & 95.7537 & 0.0232 & 42.9423 & 40.0776 & 0.0231 & \multirow{3}{*}{$\begin{array}{c}\text { Rejected at } \\
\mathrm{r}<=0 \text { and } \\
\text { not rejected } \\
\text { for all }\end{array}$} \\
\hline & At most 1 & 57.4088 & 69.8189 & 0.3235 & 22.5321 & 33.8769 & 0.5664 & \\
\hline & At most 2 & 34.8766 & 47.8561 & 0.4545 & 18.6217 & 27.5843 & 0.4443 & \\
\hline
\end{tabular}




\begin{tabular}{|l|l|l|l|l|l|l|l|c|}
\hline & At most 3 & 16.2550 & 29.7971 & 0.6942 & 9.1790 & 21.1316 & 0.8177 & $\begin{array}{c}\text { ranks of } \\
\text { r }>0\end{array}$ \\
\cline { 2 - 9 } & At most 4 & 7.0760 & 15.4947 & 0.5688 & 6.1751 & 14.2646 & 0.5908 & \\
\cline { 2 - 9 } & At most 5 & 0.9009 & 3.8415 & 0.3425 & 0.9009 & 3.8415 & 0.3425 & \\
\hline
\end{tabular}

Table 8. Model with Linear deterministic trend with constant restriction

\begin{tabular}{|c|c|c|c|c|c|c|c|c|}
\hline \multicolumn{9}{|c|}{ Linear deterministic Trend (restricted - in first differences) } \\
\hline \multirow[t]{2}{*}{ Variables } & & \multicolumn{3}{|c|}{ Trace - Rank Test } & \multicolumn{3}{|c|}{ Lambda-Max Test } & \multirow[b]{2}{*}{$\begin{array}{l}\text { Hypothesis } \\
\text { of "No Co- } \\
\text { integration" }\end{array}$} \\
\hline & $\begin{array}{c}\text { Hypothesi } \\
\text { zed No. of } \\
\text { CE(s) }\end{array}$ & $\begin{array}{c}\text { Trace } \\
\text { Stat }\end{array}$ & $\begin{array}{c}\text { Critical } \\
\text { value at } \\
5 \%\end{array}$ & Prob. & $\begin{array}{c}\text { Lambda } \\
\text {-Max }\end{array}$ & $\begin{array}{c}\text { Critical } \\
\text { value at } \\
5 \%\end{array}$ & Prob. & \\
\hline \multirow{6}{*}{$\begin{array}{l}\text { LBHU, } \\
\text { LBSE, } \\
\text { LNPL, } \\
\text { LBGD, } \\
\text { LSLK, } \\
\text { LPAK }\end{array}$} & None & 123.3879 & 117.7082 & 0.0207 & 47.0428 & 44.4972 & 0.0258 & \multirow{6}{*}{$\begin{array}{c}\text { Rejected at } \\
r<=0 \text { and not } \\
\text { rejected for } \\
\text { all ranks of } \\
r>0\end{array}$} \\
\hline & At most 1 & 76.3450 & 88.8038 & 0.2810 & 34.2436 & 38.3310 & 0.1370 & \\
\hline & At most 2 & 42.1014 & 63.8761 & 0.7729 & 18.8185 & 32.1183 & 0.7428 & \\
\hline & At most 3 & 23.2830 & 42.9153 & 0.8670 & 11.5544 & 25.8232 & 0.8987 & \\
\hline & At most 4 & 11.7286 & 25.8721 & 0.8304 & 7.8625 & 19.3870 & 0.8336 & \\
\hline & At most 5 & 3.8661 & 12.5180 & 0.7614 & 3.8661 & 12.5180 & 0.7614 & \\
\hline
\end{tabular}

\section{CONCLUSION}

This paper concludes that all the stock indices in South Asian region (six countries included in this study) have unit root presence or data non-stationary at the same order level while they are all stationary at first level differencing. There is no evidence of long-term market relationship between any of the stock market on one to one basis except for very weak association between Bhutan and India. Subhani, Hasan, Mehar and Osman (2011) also found that on a one to one basis there is no evidence of comovements between Pakistani and Indian market and between Pakistani and Nepalese market. However, this paper does not support their findings, "the South Asian stock markets as a whole are co-integrated with each other". We have run all the equations with (no deterministic trend, no deterministic trend with restricted constant, linear deterministic trend, linear deterministic trend with restricted constant) with log data but failed to reject the null hypothesis of "no cointegration" at less than 5\% significance level for $r>0$. Difference in findings may be due to difference in data coverage. They studied four countries data (Pakistan, Bangladesh, Nepal and India) for May 1995 - May 2011 period; we covered six countries for 2006 2011 period. As far as our study goes, we can conveniently conclude that the long-term relationship between South Asian stock market is very weak. Implication of such a findings is that investors in the region have opportunity to minimize risk at the similar levels of returns or maximize return at a given level of risk, if the markets were open for capital mobility.

\section{REFERENCES}

1. Chowdhury, A.R. (1994), "Stock market interdependencies: Evidence from the Asian NIEs", Journal of Macroeconomics, Vol. 4, pp. 629 651.

2. Dickey, D.A. Fuller, W.A. (1976), "Likelihood Ratio Statistics for Autoregressive Time Series with Unit Root", Econometrica, Vol. 49, pp. 1057 - 1072

3. Dickey, D.A. Fuller, W.A. (1979), 'Distribution of the Estimators for 
Autoregressive Time-series with Unit Root', Journal of the American Statistical Association, Vo. 74. Pp. $427-431$.

4. Dubey, M (2007), 'SAARC and South Asian Economic Integration', Economic and Political weekly (April 7), pp. 1230 -1240.

5. Engle, R.F, Granger, C.W.J. (1987), " Co-integration and errorcorrection: Representation, estimation and testing, Econometrica, Vol.55, pp. $251-$ 276.

6. Gunasinghe, W.I.C.S. (2005), "Behaviour of Stock Markets in South Asia: An econometric Investigation", Accounting and Finance, Vol. 44 (3), pp. 419 - 439.

7. Johansen, S. (1988a), "The mathematical structure of error correction models", Contemporary Mathematics, Vol. 12, pp. 359 386.

8. Johansen, S. (1988b), "Statistical analysis of co-integration vectors", Journal of Economic Dynamics and Control, Vol. 12, pp. $231-254$.

9. Johansen, S. Juselius, K. (1990), "Maximum likelihood estimation and inference on co-integration with application to the demand for money", Oxford Bulletin of Economics and Statistics, Vol. 52, pp. $169-210$.

10. Kasa, K. (1992), "Common stochastic trends in international stock markets", Journal of Monetary Economics, Vol. 29, pp. 95 - 124.

11. Khan, M.M.H. Huq, U.R. (2012), "Distribution of Risk and Return: A Statistical Test of Normality on Dhaka Stock Exchange", Research Journal of Finance and Accounting, Vol. 3, No. 3 (retrieved from www.iiste.org)

12. Lamba, A.S. (2005), "An Analysis of the Short and Long-Run Relationships between South Asian and Developed Equity Markets", International Journal of Business, Vol. 10 (4).

13. Linter, J. (1991), "Security price, risk and maximum gains from diversification" Journal of Finance, Vol. 20, pp. $587-616$.

14. Markowitz, H. (1952), "Portfolio Selection", Journal of Finance, Vol. 7, pp. 77 -91.

15. Masih, A.M.M. and Masih, R. (1996), "Common stochastic trends, multivariate market efficiency and the temporal causal dynamics in a system of daily spot exchange rates", Applied Financial Economics, 6, 495-504.

16. Mohsin, H.M. Qayyum, A. (2005), "The Integration of Financial Markets: Empirical Evidence from South Asian Countries", MPRA Paper No. 2364. (Available at www.pide.org.pk)

17. Mukherjee, K.N. (2004), "Review of Stock Market Integration: An International Perspective", ICFAI Journal of Applied Economics (Available http://papers.ssrn.com/sol3/papers.cf $\underline{\mathrm{m}}$ ?)

18. Pindyck, R.S. Rubinfeld, D.L. (1991), “ Econometric Models \& Economic Forecasts", (third edition), McGraw-Hill, Inc.

19. 19. Raj, J. Dhal, S. (2008), "Integration of India's stock market with global and major regional markets", BIS Papers No. 42.

20. Saha M. Bhunia, A. (2012), “ Financial Market Integration of South Asian Countries", Developing Countries Studies, Vo. 2, No. 1, pp. 45 - 52. (Available at www.iiste.org).

21. Sharma, G.D. Bodla, B.S. (2011), "Inter-linkages among stock markets of South Asia", Asia-Pacific Journal of Business Administration, Vol. 3 No. 2, pp. $132-148$. 
22. Sharpe, W. (1964), “ Capital asset prices: A theory of market equilibrium under conditions of risk", Journal of Finance, Vol. 19, pp. $425-442$.

23. Subhani, M.I. Hasan, S. A. Mehar, A. Osman, A. (2011), "Are the Major South Asian Equity Markets Co-integrated?", International Journal of Humanities and Social Science, Vol.1, No.12, pp. 117 121.

24. Tong, W.H.S. (2001), "Cointegration, Efficiency and Forecasting in the Currency Market", Journal of Business Finance and Accounting, Vol. 28, pp. $127-150$. 